\title{
The Dynamic Synergies between Agriculture Output and Economic Growth in Malaysia
}

\author{
Hylmee Matahir ${ }^{1} \&$ Jasman Tuyon $^{1}$ \\ ${ }^{1}$ Faculty of Business Management, Universiti Teknologi MARA (UiTM), Sabah, Malaysia \\ Correspondence: Jasman Tuyon, Faculty of Business Management, Universiti Teknologi MARA (UiTM), Sabah, \\ Malaysia. E-mail: jasmantuyon@yahoo.co.uk
}

Received: October 30, 2012

Accepted: February 22, $2013 \quad$ Online Published: March 18, 2013

doi:10.5539/ijef.v5n4p61

URL: http://dx.doi.org/10.5539/ijef.v5n4p61

\begin{abstract}
This paper investigates the dynamic synergies between agriculture sector and economic growth in Malaysia throughout historical economic policy adjustments spanning from 1970 to 2010. From the analysis, the contribution of agriculture sector output to the Malaysian economy has been decreasing despite several agriculture-led economic growth policies that have been implemented, including the very recent New Economic Model (NEM). Specifically, we employ Johansen-Juselius (1990) cointegration test and reveals that agriculture and economic growth were found to be moving together in the long run. Moreover, we examine the direction of causality between agriculture output and economic growth within the vector error-correction model (VECM). The test shows that both agriculture and economic growth have no causality direction at least in the short run but there exist a bi-directional causality movement in the long run. From this empirical testing and policy analysis, we can suggest that policy makers should pay attention to the holistic and sustainable development of agriculture sector into their policy modelling in promoting sustainable economic growth.
\end{abstract}

Keywords: agriculture economics, economic dynamism, economic sustainability, cointegration and causality analysis

\section{Introduction}

\subsection{The Role and Issues of Agriculture Sector in the Global Economy}

Agricultural economists have long been convinced and investigated the agricultural sector contribution to the overall economic growth (Wong, 2007). Theoretically, the agriculture sector contributes to the economic growth through a variety of linkages (Johnston and Mellor, 1961) and spill-over effects. It has been empirically supported that this sector is strategically important for agriculture-dependent emerging economies in Southeast Asia backed by their rich natural resources and dependency of national income to this sector (Rahman, 1998). However, despite of the significant important of agriculture sector, many developing countries have neglected and abandoned this sector in the mid 1980s (Wong, 2007; Bazemer and Headey, 2008; Headey, et. al., 2010; Dethier and Effenberger, 2011) as every countries were moving towards industrialization agenda to spur economic growth inspired by industrialise-based economic development in developed countries.

Today, many have realised that the significant important of the agriculture sector remain relevant and the future hope and roles of agriculture sector will always remain as an important sector to both developed and developing countries globally (Dethier and Effenberger, 2011). A vibrant agriculture sector has been the basis for a successful economic transformation in many developed countries and many of the developing countries are on the pathway in transforming their agriculture sector (FAO, 2009). The important roles of agriculture sector to the global society and economies are multifaceted. Agriculture sector is essential to human survival and eco-system sustainability (Murad, et. al., 2008). This sector are sole producer and supplier of foods and fibres to feed a growing population, supply feedstock for new and expanding biotechnology industry, important to socio-economic well being of many agriculture-dependent developing countries (FAO, 2009) and supply of raw materials for industries (Wahab, 2011). However, historical trend indicates that despite the increase in global demand for agricultural products, production growth has been declining (Shamsudin, 2010). Globally, critical issues in agriculture sector remain challenging for the growth of this industry and require collective strategic and sustainable solutions. These included among others; agriculture production growth rate declining, underinvestment in agriculture, higher energy prices (Shamsudin, 2010), food crisis issues (Fuglie, 2008), and 
sustainable development issues (Murad, et. al., 2008; Headey, et. al. 2010).

Empirically, there are number of studies investigating the significant contribution of agriculture sector to economic growth in other countries. In China, the contribution of agriculture sector to the economic growth depends on the government policy. Yao (2000) point out that agriculture sector could promote the growth of other sectors however those sectors were not supportive to agriculture sector. Awokuse (2009) have shown that agriculture sector could play as an engine of growth in the selected Africa, Asia and Latin America countries. Katircioglu (2006) found bidirectional causal relationship in Cyprus. On the other hand, Chebbi (2010) found that agriculture sector plays a limited role to the economic growth in the short run compare to non-agriculture sectors. Recently, Jatuporn et. al. (2011) found a long-run relationship between agriculture and economic growth for Thailand economy. Meanwhile, Datt and Ravallion (1996), Gardner (2003) and Tiffin and Irz (2006) have applied panel analysis in investigating the important of agriculture sector to the economic growth in developing countries. Their results indicated a causality direction significant from agriculture to economic growth. However, for developed countries, the results were unclear as reported in Tiffin and Irz (2006).

Despite the theoretical and empirical importance of this sector to socio-economic development in general, there is limited research investigating these issues. Furthermore, the important of agriculture productivity to socio-economic development has not been well understood (Headey, 2010) and some have neglected this golden sector. Specifically, in Malaysia, the agriculture is the critical sector nowadays because the share of output to GDP deteriorating over time despite the importance and increasing development expenditure allocated for this sector. Moreover, the government's policy to increase the participation of private sector under the New Economic Model is still unclear. Based on the these premises, this paper will explore the linkages of agriculture sector with economic growth in Malaysia with twofold objectives; first, to investigate the relationship between agriculture sector and economic growth in Malaysia by employing Johansen - Jesulius Cointegration Test.; and second, to examine the role of agriculture sector on economic growth in Malaysia. The rest of the paper is organized as follow; the next section provides the review of agriculture sector and economic structural changes in Malaysia. This is followed by an elaboration of data and econometric techniques employed. The subsequent section provides the analysis and discussion of the findings. The last section concludes this paper with strategic recommendation for development of agriculture sector in Malaysia.

\subsection{Review of Agricultural Sector and Structural Changes in Malaysia}

In Malaysia, the agriculture sector which includes livestock, fisheries and forestry plays an important role in socio-economic development. Agriculture and rural development in Malaysia are inextricably linked and has been the niche industry for Malaysia since its independence in 1957 backed by its rich and quality agriculture land bank, blessed with fertile soil, abundant rainfall, and suitable climate for food production (Frost and Sullivan, 2009; Ahmad and Suntharalingam, 2009; Matahir, 2012). Specifically, the agriculture sector plays an important role in Malaysia's economy development through provision of rural employment, uplifting rural incomes and ensuring national food security (Pemandu, pp. 41). Today, Malaysia is still basically an agricultural country though it is fast developing into an industrial country (Murad, et. al., 2008). Malaysia has about 4.06 million hectares of agricultural land and $80 \%$ of this land is cultivated with industrial corps such as palm oil, rubber, cocoa, coconut and pepper (Onn, 1990; Murad, et. al., 2008) and some allocated for agro-food production (Frost and Sullivan, 2009). The agriculture sector contributed RM20 billion or 4\% of Malaysia's gross national income (GNI) in 2009. However, economic development policy shifted from agriculture-based economy to industrial-based economy in the mid 1980 caused the public and private sector to neglect this golden market share and subsequently lost its momentum contribution to GDP growth. The following table 1, 2 and 3 explain the historical contribution of agriculture sector to Malaysian's socio-economic development.

Table 1. Relative contribution of agriculture sector to the national economy (\%)

\begin{tabular}{lllllllllll}
\hline Sector & 1970 & 1980 & 1990 & 1995 & 2000 & 2006 & 2007 & 2008 & 2009 & 2010 \\
\hline Real GDP (\%) & 2.3 & 6.6 & 9.3 & 5.2 & 5.2 & 5.8 & 6.3 & 5.7 & -2.6 & 5.9 \\
\hline Agriculture, forestry, fishing & 29.0 & 22.9 & 18.7 & 13.6 & 10.5 & 8.0 & 7.6 & 7.5 & 7.7 & 7.5 \\
Mining and quarrying & 13.7 & 10.1 & 9.7 & 7.4 & 5.7 & 8.8 & 8.5 & 7.9 & 7.7 & 7.5 \\
Manufacturing & 13.9 & 19.6 & 27.0 & 33.1 & 37.5 & 30.9 & 29.9 & 28.9 & 26.6 & 26.7 \\
Construction & 3.8 & 4.6 & 3.5 & 4.4 & 4.8 & 3.1 & 3.1 & 3.1 & 3.3 & 3.3 \\
Services & 39.6 & 42.8 & 42.1 & 44.2 & 45.7 & 51.9 & 53.8 & 55.2 & 57.6 & 57.8 \\
\hline
\end{tabular}

Source: Malaysia Second Outline Perspective Plan (1991); Seven Malaysia Plan (1996); Tenth Malaysia Plan (2010). 
Table 2. Agriculture in the Malaysian economy

\begin{tabular}{lllll}
\hline & & \multicolumn{3}{l}{ Agriculture Sector } \\
\cline { 3 - 5 } Year & GDP Growth (\%) & Growth (\%) & Share in GDP (\%) & Share in Employment (\%) \\
\hline $1970-74$ & 2.3 & 3.4 & 25.5 & 50.9 \\
$1975-79$ & 7.3 & 5.2 & 23.3 & 46.4 \\
$1980-84$ & 6.6 & 3.4 & 20.4 & 39.5 \\
$1985-89$ & 4.8 & 4.3 & 19.1 & 32.4 \\
$1990-94$ & 9.3 & 0.2 & 15.3 & 26.9 \\
$1995-99$ & 5.2 & 0.1 & 10.1 & 17.9 \\
$2000-04$ & 5.2 & 3.8 & 8.7 & 15.0 \\
2005 & 5.3 & 2.6 & 8.5 & 12.9 \\
2006 & 5.8 & 5.4 & 8.0 & 12.5 \\
2007 & 6.3 & 2.2 & 7.6 & 12.2 \\
2008 & 5.7 & 4.3 & 7.5 & 12.0 \\
2009 & -2.6 & 0.4 & 7.7 & 12.0 \\
2010 & 5.9 & 3.8 & 7.5 & 11.0 \\
\hline
\end{tabular}

Source: Adapted from Athukorala and Loke (2009), Pemandu (2010), and Tenth Malaysia Plan (2010).

Table 3. Agriculture and rural development expenditure

\begin{tabular}{llll}
\hline 5 Years Malaysia Plan & Year & Agriculture Development Expenditure (RM Million) & Agriculture Growth (\%) \\
\hline Tenth Malaysia Plan & $2011-2015$ & $\mathrm{n} / \mathrm{a}$ & $\mathrm{n} / \mathrm{a}$ \\
Ninth Malaysia Plan & $2006-2010$ & 11,435 & 3.0 \\
Eight Malaysia Plan & $2001-2005$ & 7,860 & 3.2 \\
Seventh Malaysia Plan & $1996-2000$ & 8,286 & 0.1 \\
Sixth Malaysia Plan & $1990-1995$ & 8,708 & 0.2 \\
Fifth Malaysia Plan & $1986-1990$ & 11,799 & 4.3 \\
Fourth Malaysia Plan & $1981-1985$ & 8,727 & 3.4 \\
Third Malaysia Plan & $1976-1980$ & 2,386 & 5.2 \\
Second Malaysia Plan & $1971-1975$ & 1,921 & 3.4 \\
First Malaysia Plan & $1966-1970$ & 1,114 & $\mathrm{n} / \mathrm{a}$ \\
\hline
\end{tabular}

Source: Available at http://www.pmo.gov.my; n/a denotes - data not available.

\subsubsection{Agrarian-Based Economy Era: $1957-1985\left(1^{\text {st }} \mathrm{MP}-4^{\text {th }}\right.$ MP $)$}

During this agricultural-dependant era, the development of agriculture sector played important roles in both socio-economic developments in Malaysia. In terms of social contribution, this sector is strategically important as a source of income and increases the living standards of the majority rural poor. While, in terms of economic contribution, this sector is a source of food and raw material supplier for industrial sector. Efforts extended by both public and private sectors in development of this sector had enable the agricultural production grew at the rate of 4.8\% annually between 1960 and 1965. Under the First Malaysian Plan: 1956-1960, the government allocated RM478.2 million or $47.5 \%$ of its total public development expenditure for agriculture and rural development. The government strong support for agriculture sector continued in the Second Malaya Plan: 1961-1965, The First Malaysia Plan: 1966-1970, The Second Malaysia Plan: 1971-1975, The Third Malaysia Plan: 1976-1980, and The Fourth Malaysia Plan: 1981-1985. In 1960, the agriculture sector contributed about $44 \%$ to the Malaysia's GDP (Frost and Sullivan, 2009) spurred by agriculture-based economy development policy focus. During this era, about $70 \%$ of the population were resided and engaged in agricultural activities in rural areas (Arshad and Shamsudin, 1997). However, the global recession which occurred in the early 1980s caused sharp declined in the commodity prices resulting in the GDP growth rate declined from $8 \%$ in 1982 to $-1 \%$ in 1986 (Onn, 1990). Agriculture sector problems during this era including; inadequate technical capacity, risk of volatile rubber prices and lack of incentives for agricultural production. Since then, the multifaceted problems encountered in agriculture sector, discourage the growth of this sector (Rahman, 1998).

1.2.2 Industrialized Economy Era: $1986-2000\left(5^{\text {th }} \mathrm{MP}-7^{\text {th }} \mathrm{MP}\right)$

The limitation of economy dependency to agriculture sector bring about the ideas of diversifying the Malaysian economic structure to a more broad-based industrial economy (Onn, 1990) in the second wave of economic structural change. The industrialization era in Malaysia had started in the mid-1980s (Ahmad and 
Suntharalingam, 2009). During this time, aggressive industrialization efforts had turned the manufacturing to become the leading sector of the economy and left agriculture in the back seat of the economy policy focus (Ahmad and Suntharalingam, 2009). The government economic development policies during this period have been focused on manufacturing and services (Rahman, 1998) and (Lim, 1991; Ahmad, et. al. 1993) as reported in Ahmad and Suntharalingam (2009). The government has been giving too much emphasis on the industrial sector, hence marginalising the agricultural sector (Ahmad, et. al., 2001). However, the agriculture sector development was back on the economic development agenda after the Asian financial crisis in 1997/98 (Ahmad and Suntharalingam, 2009; M. Shaffril, et. al., 2010). This is part of the strategy undertaken to strengthen the domestic economy position to curve external economic shock. In this regards, the First National Agricultural Policy: 1984-1991, was launched in January 1984 outlined the long-term development framework for agriculture sector in Malaysia $\left(5^{\text {th }} \mathrm{MP}\right.$ ). During this era, the agriculture sector development policy had emphasised on development of new agricultural lands. The government had allocated higher development expenditure for agriculture sector amounting to RM 11,799 million in the fifth Malaysia Plan.

\subsubsection{Broad-Based Economy Era: $2001-2010\left(8^{\text {th }} \mathrm{MP}-9^{\text {th }}\right.$ MP $)$}

This era was aim to balance and to sustain the economic development policies. Attention to agriculture sector continued in the economic development policy radar, drawing attention to the impacts of agricultural productivity on economic growth, social issues and environmental issues (Murad, et. al., 2008; Bezemer and Heady, 2008; Heady, et. al., 2010). Additionally, the global slowdown has in turn affected the Malaysian economy which contracted by $1.7 \%$ in 2009. Given the openness of the Malaysian economy, the negative wealth effects of the global crisis on demand and world trade have resulted in a decline in industrial production and manufacturing exports $\left(9^{\text {th }} \mathrm{MP}\right)$. During this period, the government had taken policy initiatives to further energized the agriculture sector growth under the Second National Agricultural Policy: 1992-2010 and the Third National Agricultural Policy: 1998-2010 aiming for high agricultural productivity while ensuring conservation and utilization of natural resources on a sustainable basis (Murad, et.al., 2008). Further pro-agriculture policy is provided under the Ninth Malaysia Plan: 2006-2010 with highest allocation of RM 11,435 million to re-emphasis on growth and rebrand the agriculture sector as agribusiness. Specifically, during the ninth Malaysia Plan period, the overall policy thrusts of the agriculture sector had been focusing on its reorientation towards greater commercialisation and the creation of high-income farmers as well as promotion of greater private sector investment including foreign investment. With the support from both the public and private sector, the agriculture sector has been transformed from rural agriculture to commodities based agriculture practices (Frost and Sullivan, 2009). This strategy partly contributed to the nation transformation from an agricultural and commodity-based economy to become a prosperous thriving middle-income nation. Malaysia's real Gross Domestic Product (GDP) has grown by an average of 5.8\% per annum from 1991 to 2010. However, the expected agriculture sector average annual growth rate of 5.0 per cent under the ninth Malaysia Plan is still far to be achieved.

\subsubsection{New Economic Model Era: $2011-2015\left(10^{\text {th }} \mathrm{MP}\right)$}

The latest New Economic Model (NEM) was launched in 2010 by the current Prime Minister. The main goal of NEM is to achieve a high income nation by 2020 with inclusiveness and sustainable socio-economic policies. NEM provides a new paradigm of development thinking with a more balanced and sustainable socio-economic growth focus (Arshad, 2010). In summary, NEM bring about the economic transformation (ETP) ideas with strategic development focus on 12 National Key Economic Areas (NKEAs) through 131 entry point projects. Agriculture sector is one of the NEM's NKEAs. The agriculture NKEA will focus on selected eight sub-sectors which has high-growth potential, namely food processing, cash crops (fruits and vegetables) other products (seaweed farming, swiftlet nests, herbal products), livestock, marine and aquaculture products as well as paddy rice. This sub-sectors account for $82 \%$ of agriculture's contribution to Malaysian GNI in 2009 (Pemandu, pp. 514-515). The agriculture's NKEA targeted the agriculture sector will be transformed into agribusiness by 2020 through inclusive demand-driven approach focusing on market needs, economies of scale and value chain integration (Pemandu, pp. 41). Specifically, the agriculture's NKEA targeted to raise total GNI contribution to reach RM49 billion by 2020 and expected to create additional 75,000 jobs mostly in rural areas. This program will require cumulative funding of RM22 billion for the next 10 years with $62 \%$ is to be generated from private sector (Pemandu, pp. 42).

However, according to some industry experts, there are few strategic agricultural sector issues that need immediate attention and policy makers' consideration. First issue; the agriculture sector contains the heaviest government involvement in business activities since in the 1970s (Arshad, 2010) from upstream and downstream activities as well as in the agriculture sector value chain system and trade mechanism. Those days, the 
agriculture sector perceived by private sector players as high risk industry and the government interventions is necessary and aiming at growing and protecting this industry sector growth. At the current economic scenario, Arshad (2010) argue that this is no longer applicable and suggesting that Malaysia has to re-look at the economic relevancy of the government massive intervention and involvement in the agriculture sector. Second issue; In Malaysia, agriculture holds the key to issues such as food security and safety, climate change, resource conservation, biodiversity and poverty reduction (Arshad, 2010). As such, this sector is significantly important to partly support the achievement of prosperity and sustainable socio-economic development in the coming and foreseeable future in Malaysia. Third issues; the achievement of Malaysia to become a high income country is challenged by its ability to uplift the bottom $40 \%$ poor population that are mainly resided in the rural areas (Arshad, 2010) of which dependable on agriculture sector. Thus, The policy makers need to understand the important of agriculture sector in holistic economic development perspectives and provide support for sustainable pro-agriculture growth policy in new economic model era for a more balanced and sustainable socio-economic development.

\section{Data and Methodology}

We obtain series of annual Malaysian's agriculture output and GDP in real term (based year 2005) from the World Bank and the Department of Statistics, Malaysia from 1970 to 2010. These variables have been transformed into log-form.

\subsection{Econometric Techniques}

\subsubsection{Unit Root Test}

According to Nelson and Plosser (1982), most of macroeconomic data are spurious because it contents the problem of instability. Moreover, Granger and Newbold (1974), and Engle and Granger (1987) argued that regressing the non-stationarity data from conventional OLS method would result in spurious outcome. Therefore, it becomes fundamental procedure when dealing with time series data to determine the stationarity of them to show whether all the data have the same order of integration. In this paper, we employ three widely applied unit root tests, namely Augmented Dickey-Fuller (ADF) (1979), Phillips-Perron (PP) (1988) and Kwiatkowski, Phillips, Schmidt and Shin (KPSS) (1992).

\subsubsection{Johansen - Jesulius Cointegration}

This paper will utilize Johansen and Jesulius Cointegration (1990) approach. Several authors revealed that this approach is performing better than other cointegration tests (Gonzalo 1994). In conducting the Johansen cointegration test, all the variables must have the same order of integration. We estimate the following model:

$$
\Delta y_{t}=\Pi y_{t-1}+\sum_{t=1}^{p-1} \Gamma_{t} \Delta y_{t-1}+v_{t}
$$

Where $\Pi=\sum_{t=1}^{p} A_{t}-I$ and $\Gamma=-\sum_{j=i+1}^{p} A_{t} \cdot \Delta$ is the first different operators; $y_{t}$ is $k \times 1$ stochastic vector of endogenous variables (our studies are consists $\ln \mathrm{Ag}_{t}$ and $\operatorname{lnGDP}$ ) and $v_{t}$ is the error term. The matrix $\Pi$ consists of long run information between $y_{t}$ variables in the vector. We will examine the matrix rank, $r$, by testing the null hypothesis that the eigenvalues $\Pi$ is statistically different from zero. If $\Pi$ has zero $r$, we could not identify the stationary linear combination and the variables in $y_{t}$ are not cointegrated. However, we can decompose into two matrices such that $\Pi=\alpha \beta^{\prime}$, where $\alpha$ indicate the speed of adjustment to equilibrium relationship, while $\beta$ is the cointegrating vector. Two set of Likelihood ratio tests suggested by Johansen and Juselius (1990) then we employ to test the existence of long run equilibrium relationship among variables; (1) trace test, $L R\left(\lambda_{\text {trace }}\right)=-T \sum_{i=r+1}^{k} \ln \left(1-\lambda_{i}\right)$ and (2) maximum eigenvalues test, $L R\left(\lambda_{\max }\right)=-T \ln \left(1-\lambda_{i+1}\right) . T$ is the number of observations and $\lambda_{i+1}$ is the eigenvalues $\left(\lambda_{1}>\lambda_{2} \ldots>\lambda_{k}\right)$. We used Pantula principle as suggested by Hansen and Juselius (1994) to choose the appropriate cointegration model.

Having determined the cointegration among variables, we then employ Granger Causality test to indicate the causal direction of the variables. The following models were estimated:

$$
\Delta \ln a g_{t}=\gamma_{11} e c t_{t-1}+\sum_{i=1}^{p} \phi_{1 i} \Delta \ln a g_{t-i}+\sum_{j=1}^{q} \varphi_{1 j} \Delta \ln g d p_{t-j}+\mu_{1 t}
$$




$$
\Delta \ln g d p_{t}=\gamma_{21} e c t_{t-1}+\sum_{i=1}^{p} \phi_{2 i} \Delta \ln a g_{t-i}+\sum_{j=1}^{q} \varphi_{2 j} \Delta \ln g d p_{t-j}+\mu_{2 t}
$$

From the equation (2) and (3) above, $\gamma_{11}$ and $\gamma_{21}$ are the coefficients measure the error correction term, $e c t_{t-1}$. Meanwhile $e c t_{t-1}$ is the error-correction term with lag one, derive from normalized cointegrating vector. The long run causality relationship exist if $e c t_{t-1}$ is significant. The $\Delta$ is indicates the first difference explanatory variables. In other word, it represent the variables are in the short run form, $\mu_{1 t}$ and $\mu_{2 t}$ are the error term of the respective equations which follow the i.i.d criteria. To test the existence of the causality relationship in eq. (2), the $H_{0}: \varphi_{1 j}=0$ of no causality is tested using the standard Wald test. If we fail to reject the null hypothesis means that there is no causality running from real GDP to agriculture output. Similarly for eq. (3), if we fail to reject the null hypothesis, $H_{0}: \phi_{2 j}=0$, we conclude that there is no causal relationship running from agriculture output to real GDP. In causal analysis, there are three results will appear, (1) bidirectional causality; both agriculture and real GDP has causal relationship running from each other, (2) one-way causality direction; only one variable causes the other, and (3) no causality; the two variables do not have causality direction.

\section{Results and Discussion}

In our case, if the two variables, lnag and lnGDP are integrated at the same level, both the variables could have long run equilibrium. In doing so, Augmented Dickey-Fuller (ADF) (1979), Phillips-Perron (PP) (1988) and Kwiatkowski, Phillips, Schmidt and Shin (KPSS) (1992) have been employed to determine the level of integration of the variables. From table 4, all the three tests have shown that the selected variables are not stationary at level but there are stationary after first differencing even though for KPSS test, the agriculture output is rejected at $10 \%$ significant level. Therefore we can conclude that all the selected variables have the same order of integration, $I(1)$.

Table 4. Unit root test

\begin{tabular}{llll}
\hline Variables & ADF test & PP & KPSS \\
\hline Level & & & \\
$\ln$ ag & -2.248 & -2.440 & $0.771^{* *}$ \\
$\ln$ GDP & -1.725 & -1.672 & $0.793^{*}$ \\
First difference & & & \\
$\Delta$ ln ag & $-6.210^{*}$ & $-6.225^{*}$ & $0.366^{* * *}$ \\
$\Delta \ln$ GDP & $-5.258^{*}$ & $-5.299^{*}$ & 0.261 \\
\hline
\end{tabular}

Notes: *,**,** significant at $1 \%, 5 \%$ and $10 \%$. ADF and PP critical value are based on MacKinnon (1996) one-sided p-values. KPSS critical values are based on Kwiatkowski-Phillips-Shin (1992, table 1). Lag length criteria follows AIC criterion.

Having determined the level of integration of the selected variables, we then performed the Johansen and Juselius (1990) co-integration test and results are as reported in table 5. It clearly shows that the trace and max eigenvalue statistics is rejected at $5 \%$, suggesting the existence of one cointegration rank between the variables. The normalized cointegration vector shows that real GDP has a positive relationship with agriculture output. It suggests that an increase in agriculture output as much as $1 \%$, real GDP will increase by $4.9 \%$ and this value is significant at $5 \%$.

Table 5. Cointegration test

\begin{tabular}{llllll}
\hline \multicolumn{5}{l}{ Panel A: Johansen cointegraion results } \\
\hline \multicolumn{5}{l}{ Hypothesis } & LR test statistics \\
\hline$H_{0}$ & $H_{1}$ & $L R\left(\lambda_{\text {trace }}\right)$ & $L R\left(\lambda_{\max }\right)$ & $L R\left(\lambda_{\text {trace }}\right)$ & $L R\left(\lambda_{\max }\right)$ \\
\hline$r \geq 0$ & $r \geq 1$ & $32.5698^{*}$ & $25.6567^{*}$ & 20.2618 & 15.8921 \\
$r \geq 1$ & $r \geq 2$ & 6.9131 & 6.9131 & 9.1645 & 9.1645 \\
\hline Panel B: Normalized cointegrating vector & Constant & \\
\hline $\ln g d p_{t}$ & $\ln a g_{t}$ & -153.062 & \\
\hline 1.000 & $4.9536^{* *}$ & $(67.22)$ & & \\
& $(2.792)$ & & & \\
\hline
\end{tabular}

Notes: ${ }^{*}, *$, are significant at $1 \%$ and $5 \%$. 
The existence of cointegration among variables does not represent direction of causality between the variables. As discussed from the earlier section, we employ a VECM Granger causality to examine the nature of interdependence between agriculture output and economic growth, and the results are reported in table 6 below. Firstly, we estimate the OLS of eq. (2) and eq. (3) as reported in panel (A) and then we employs VECM Granger causality test to detect any direction of causality between agriculture sector and economic growth. In the short run, both real GDP and agriculture output are identical or not relating to each other because we cannot reject the null hypothesis of no causality. However, in the long run analysis shows the $E C T_{\mathrm{t}}$ were rejected at $1 \%$ level of significant. We can suggest that both economic growth as proxy by real GDP and agriculture sector output has a bidirectional causality running from each other. In other words, agriculture becomes an influence factor that could promote the economic growth in the long run. Similarly, an increase of GDP also could contribute to the increase in the agriculture output production in the long run. For example, eq. (2) that there is a long run relationship between real GDP and agriculture output. After short-run shocks, real GDP will deviate $0.53 \%$ to achieve equilibrium. Similarly to eq. (3) that we find a causality direction from agriculture to real GDP and they will converge to achieve equilibrium in the long run for almost $0.7 \%$. Apart from that, panel (C) of the table we provide diagnostic tests to ensure the reliability of the model. For LM test shows that the residuals of the two models were free from serially correlated as we cannot reject the null hypothesis and we also found that the residuals are normally distributed as show from the normality test.

Table 6. Causality test

\begin{tabular}{|c|c|c|c|c|}
\hline \multicolumn{5}{|c|}{ Panel A: Estimation result for equation (2) and (3) } \\
\hline \multicolumn{2}{|c|}{ Independent variables } & $\Delta \operatorname{lnag}_{\mathrm{t}}$ & \multicolumn{2}{|l|}{$\Delta \operatorname{lnGDP}{ }_{t}$} \\
\hline \multicolumn{2}{|c|}{$\Delta \operatorname{lnag}_{\mathrm{t}-1}$} & -0.0276 & \multicolumn{2}{|l|}{-0.2441} \\
\hline \multicolumn{2}{|l|}{$\Delta \operatorname{lnGDP}{ }_{t-1}$} & -0.2277 & \multicolumn{2}{|l|}{0.1905} \\
\hline \multicolumn{2}{|l|}{$\mathrm{ECT}_{\mathrm{t}-1}$} & $-0.0053 *$ & \multicolumn{2}{|l|}{$-0.0067 *$} \\
\hline \multicolumn{5}{|c|}{ Panel B: Short run and long run Granger causality } \\
\hline \multirow{2}{*}{\multicolumn{2}{|c|}{ Null hypothesis }} & \multicolumn{2}{|l|}{$\chi_{\text {-statistics }}^{2}$} & \multirow{2}{*}{$\mathrm{ECT}_{\mathrm{t}-1}$} \\
\hline & & \multicolumn{2}{|c|}{ Short run Granger non-causality test } & \\
\hline \multicolumn{2}{|c|}{ lnGDP does not granger cause lnag } & \multicolumn{2}{|c|}{2.2175} & $-0.0053 *$ \\
\hline \multicolumn{2}{|c|}{ lnag does not granger cause lnGDP } & 1.7967 & & $-0.0067 *$ \\
\hline \multicolumn{5}{|c|}{ Panel C: Stability test } \\
\hline Stability test & LM test & Normality test ${ }^{@}$ & \multicolumn{2}{|l|}{ Heteroscedasticity $^{\#}$} \\
\hline Eq. (2) & 0.1299 & 0.7526 & \multicolumn{2}{|l|}{$0.3708^{*}$} \\
\hline Eq. (3) & 0.5630 & 52.230 & \multicolumn{2}{|l|}{0.8975} \\
\hline
\end{tabular}

Notes: * denotes a rejection region at $1 \%$ level of significant. Both equation fail to reject $\mathrm{H}_{0}$ : residual is not serially correlated. \# using Bruesh-Pagan-Godfrey method.@Both equations pass the normality test as Jarques-Bera statistic shown that residual is normally distributed.

\section{Limitations}

The relationships between agriculture and economic growth is contextualizes into a narrow perspective of one to one variable relationship (i.e agriculture value added output - GDP). In this paper, we also ignored the other non-agriculture industries output in our economic structural analysis perspective.

\section{Conclusion}

The significant important of agriculture to Malaysian's socio-economic development is both theoretically and empirically supported. We re-examine this issues with a recent data to reflect the current economic environments. This paper provides empirical findings that there exist a co-integration relationship between agriculture and economic growth in Malaysia. Our findings from granger non-causality tests indicate agriculture and economic growth are identical. The increase in agriculture output seems to be no effect to the Malaysian economic growth at least in the short run, vice versa. However, in the long-run non-causality test, both variables have a feedback respond. In other words, agriculture sector output can cause economic growth and economic growth will also promote agriculture output in the long run. To recap, Malaysia development policy has re-emphasis back on the neglected agriculture sector after we experienced the 1997/98 crisis and pressured by the recent world trends in emphasising on the agriculture sector to curve the climate change and sustainable development issues. However, despite numerous efforts to revive the lost momentum of agriculture sector, the current contributions of this sector to Malaysia's GDP still not enough and unable to recover the growth rate of $44 \%$ recorded before the industrialization era as well as the targeted $5 \%$ growth rate per annum. In this respect, 
the Malaysian government should pay extra attention to the holistic and sustainable development of agriculture sector which is critical in supporting the Malaysia's 2020 vision. Otherwise, things would remain status quo.

\section{Acknowledgements}

This paper has been presented in the International Conference on Management, Economics and Finance (ICMEF2012) held on 15th - 16th October 2012 at Hilton Hotel, Kuching, Sarawak, Malaysia. We would like to thank the journal reviewers and the ICMEF2012's conference participants especially to Professor Hussain Ali Bekhet (UNITEN, Malaysia) and Mr. Rudy Kurniawan (Macquire University, Australia) for their insightful comments which have indirectly contributed in improvement of this paper.

\section{References}

Abdullah, R. N. M. (2010). New Economic Model: An Analytical Perspective. Retrieved from http://www.intanbk.intan.my/i-portal/dl/ppa2010/ahmadzubaidi.pdf

Ahmad, N. Z., Majid, A. M., \& Zaidi, S. M. A. (2001). Agricultural and Industrial Development in Malaysia: Policy Bias? Humanomics, 17(1), 61-76. http://dx.doi.org/10.1108/eb018860

Ahmad, T. T. M. A., \& Suntharalingam, C. (2009). Transformation and Economic Growth of the Malaysian Agricultural Sector. Economic and Technology Management Review, 4, 1-10.

Ali, R., Ali, A. K. A., Fatah, F. E., \& Ariff, E. E. (2010). Linkages of Macroeconomic Indicators and Agricultural Variables in Malaysia. Economic and Technology Management Review, 5, 1-9.

Arshad, M. F. (2010). Is There a New Economic Model (NEM) for Agriculture? Options, 15(1), 1-3. Retrieved from http://www.econ.upm.edu.my/ fatimah/FMA\%20Options\%20Jan\%202010.pdf

Arshad, M. F., \& Shamsudin, M. N. (1997). Rural Development Model in Malaysia. Paper presented to the Hon. President of Peru, Fujimori, Lima, Peru. Retrieved from http://www.econ.upm.edu.my/ fatimah/rural.pdf

Athukorala, P. C., \& Loke, W. H. (2009). Agricultural Incentives in Malaysia: Trends, Patterns and Policy Implications. Malaysian Journal of Economic Studies, 46(2), 151-173.

Awokuse, T. O. (2009). Does Agriculture Really Matter for Economic Growth in Developing Countries? Paper presented at the American Agricultural Economics Association Annual Meeting, Milwaukee, WI, July 26-28. $\quad$ Retrieved from http://ageconsearch.umn.edu/bitstream/49762/2/AAEA2009_Submission_Ag_Led_Growth_050109.pdf

Bezamer, D., \& Headey, D. (2008). Agricultural, Development and Urban Bias. World Development, 34, 1342-1364. http://dx.doi.org/10.1016/j.worlddev.2007.07.001

Booth, A. (2002). Rethinking the Role of Agriculture in the "East Asian" Model: Why is Southeast Asia Different from Northeast Asia? ASEAN Economic Bulletin, 19(1), 40-51. http://dx.doi.org/10.1355/AE19-1D

Chebbi, H. E. (2010). Agriculture and Economic Growth in Tunisia. China Agriculture Economic Review, 2(1), 63-78. http://dx.doi.org/10.1108/17561371011017504

Dethier, J. J., \& Effenberger, A. (2011). Agriculture and Development: A Brief Review of Literature. Policy Research Working Paper, No. 5553, The World Bank, 1-60.

Dickey, D., \& Fuller, W. A. (1979). Distributions of the Estimators for Autoregressive Time Series with a Unit Root. Journal of the American Statistical Association, 74(366), 427-431. http://dx.doi.org/10.2307/2286348

Engle, R. F., \& Granger, C. W. J. (1987). Co-integration and Error Correction: Representation, Estimation and Testing. Econometrica, 55(2), 251-276. http://dx.doi.org/10.2307/1913236

EPU. (2004). Malaysia: 30 Years of Poverty Reduction, Growth and Racial Harmony. Paper presented at Scaling Up Poverty Reduction: A Global Learning Process and Conference, Shanghai, May 25-27, 2004. Retrieved from http://info.worldbank.org/etools/docs/reducingpoverty/case/25/fullcase/Malaysia\%20Full\%20Case.pdf

FAO. (2009). Global Agriculture towards 2050. Agricultural Economics Division, FAO, Rome, Italy. Retrieved from www.fao.org/fileadmin/templates/wsfs/docs/Issues_papers/HLEF2050_Global_Agriculture

Forst and Sullivan. (2009). Overview: Malaysian Agricultural Biotechnology. Retrieved form http://www.biotechcorp.com.my/wpcontent/uploads/2011/11/publications/White_Paper_Agricultural.pdf

Fuglie, K. O. (2008). Is a Slowdown in Agricultural Productivity Growth Contributing to the Rise in Commodity Prices? Agriculture Economics, 39, 431-441. http://dx.doi.org/10.1111/j.1574-0862.2008.00349.x 
Gardner, B. (2003). Causes of Rural Economic Development. Paper presented at the $25^{\text {th }}$ International Conference of Agricultural Economists, Durban, August 16-22. Retrieved from http://purl.umn.edu/28559

Gonzalo, J. (1994). Five Alternative Methods of Estimating Long-run Equilibrium Relationships. Journal of Econometrics, 60, 203-233. http://dx.doi.org/10.1016/0304-4076(94)90044-2

Granger, C. W. J., \& Newbold, P. (1974). Spurious Regressions in Econometrics. Journal of Econometrics, 2(2), 111-120. http://dx.doi.org/10.1016/0304-4076(74)90034-7

Hansen, H., \& Juselius, K. (1995). CATS in RATS: Cointegration Analysis of Time Series. Evanston Illinois: Estima, United States.

Headey, D., Alauddin, M., \& Prasada Rao, D. S. (2010). Explaining Agricultural Productivity Growth: An International Perspective. $\quad$ Agricultural $\quad$ Economics, $41, \quad$ 1-14. http://dx.doi.org/10.1111/j.1574-0862.2009.00420.x

Ismail, F. (2007). Structural Change of the Agricultural Sector: Analysis Based on Input-Output Table. Department of Statistics, Malaysia, 1-13. Retrieved from http://www.statistics.gov.my/portal/download_journals/files/2007/Volume2/Contents_agricultural_sector.pd $\mathrm{f}$

Jatuporn, C., Chien, L. H., Sukprasert, P., \& Thaipakdee, S. (2011). Does a Long-Run Relationship Exist Between Agriculture and Economic Growth in Thailand? International Journal of Economics and Finance, 3(3), 227-233. http://dx.doi.org/10.5539/ijef.v3n3p227

Johansen, S., \& Juselius, K. (1990). Maximum Likelihood Estimation and Inference on Cointegration: With Applications to the Demand for Money. Oxford Bulletin of economics and Statistics, 52, 169-210. http://dx.doi.org/10.1111/j.1468-0084.1990.mp52002003.x

Johnston, B., \& Mellor, J. (1961). The Role of Agriculture in Economic Development. American Economic Review, 51(4), 566-593.

Katircioglu, S. T. (2006). Causality and Economic Growth in a Small Nation under Political Isolation: A Case from North Cyprus. International Journal of Social Economics, 33(4), 331-343. http://dx.doi.org/10.1108/03068290610651643

Kwiatkowski, D., Phillips, P. C. B., Schmidt, P., \& Shin, Y. (1992). Testing the Null Hypothesis of Stationarity against the Alternative of a Unit Root: How sure are we that Economic Time Series Have a Unit Root? Journal of Econometrics, 54(1-3), 159-178. http://dx.doi.org/10.1016/0304-4076(92)90104-Y

Larry, C. Y. W. (2007). Development of Malaysia's Agriculture Sector: Agriculture as an Engine of Growth? ISEAS Conference on the Malaysian Economy: Development and Challenges, 1-21. Retrieved from http://isis.org.my/attachments/386_Territorial_Disputes_in_East\%20Asia.pdf

Matahir, H. (2012). The Empirical Investigation of the Nexus between Agricultural and Industrial Sectors in Malaysia. International Journal of Business and Social Science, 3(8), 225-231.

Murad, M. W., Mustapha, N. H., \& Siwar, C. (2008). Review of Agricultural Policies with Regards to Sustainability. American Journal of Environmental Sciences, 4(6), 608-614. http://dx.doi.org/10.3844/ajessp.2008.608.614

Nelson, C. R., \& Plosser, C. I. (1982). Trends and random walks in macroeconomic time series: Some evidence

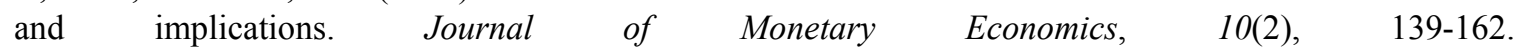
http://dx.doi.org/10.1016/0304-3932(82)90012-5

Onn, F. C. (1990). Small and Medium Industries in Malaysia: Economic Efficiency and Entrepreneurship. The Developing Economies, XXVIII(2), 152-179.

PEMANDU. (2010). Economic Transformation Programme: A Roadmap for Malaysia. Malaysia: Performance Management and Delivery Unit (PEMANDU), Prime Minister's Department.

Phillips, P. C. B., \& Perron, P. (1988). Testing for a Unit Root in Time Series Regression. Biometrika, 75(2), 335-346. http://dx.doi.org/10.1093/biomet/75.2.335

Rahman, A. A. Z. (1998). Economic Reforms and Agricultural Development in Malaysia. ASEAN Economic Bulletin, 15(1), 59-76. http://dx.doi.org/10.1355/AE15-1E

Shaffril, M. H. A., Asmuni, A., \& Ismail, A. (2010). The Ninth Malaysian Plan and Agriculture Extension Officer Competency: A Combination for Intensification of Paddy Industry in Malaysia. Journal of International 
Social Research, 3(10), 450-457.

Shamsudin, M. N. (2010). Economics of Agricultural Innovation: Experiences in Developed Economies and Policy Respond from Malaysia. Paper presented at MAHA International, $3^{\text {rd }}$ December, 2010. Retrieved from

http://www.fama.gov.my/html/themes/fama/document/Kertas_28_MAHA_Econ_Innovation_prof_Mad_Na sir.pdf

Tiffin, R., \& Irz, X. (2006). Is Agriculture the Engine of Growth? Agricultural Economics, 33(1), 79-89. http://dx.doi.org/10.1111/j.1574-0862.2006.00141.x

Wahab, A. L. (2011). An Analysis of Government Spending on Agricultural Sector and its Contribution to GDP in Nigeria. International Journal of Business and Social Science, 2(20), 244-250.

Yao, S. (2000). How Important of Agriculture of China's Economic Growth? Oxford Development Studies, 28(1), 33-49. http://dx.doi.org/10.1080/713688306 